\title{
Analisa Kinerja Angkutan Umum Penumpang Perkotaan Ditinjau Dari Tingkat Pelayanan di Kota Tuban
}

\author{
Andi Syaiful Amal*, Shaufi Kholif Arfintana, Khoirul Abadi \\ Jurusan Teknik Sipil, Fakultas Teknik, Universitas Muhammadiyah Malang \\ Kampus III Jl. Raya Tlogomas No. 246 (0341) 464318-319, Malang 65144 \\ *Correspondence email: andiamal99@yahoo.co.id
}

\begin{abstract}
Abstrak. Angkutan Umum Penumpang (AUP) di Kota Tuban adalah salah satu sarana transportasi yang digunakan masyarakat untuk memenuhi kebutuhan transportasi. Jumlah armada angkutan umum penumpang yang terdaftar dan aktif beroperasi sebanyak 40 kendaraan, terdiri dari 30 unit angkutan umum penumpang trayek A dan 10 unit angkutan umum penumpang trayek B, dengan kapasitas 12 penumpang/kend. Angkutan umum penumpang beroperasi mulai dari pukul 06.00 - 17.00, dengan jumlah perjalanan berkisar $7-8$ trip/hari setiap kendaraan, dan dapat mengangkut $9-10$ penumpang/trip setiap kendaraan. Waktu tunggu calon penumpang trayek A rata-rata 3 menit, dan trayek B rata-rata 9 menit. Tujuan dari penelitian ini yaitu untuk mengetahui kinerja dan produktivitas angkutan umum penumpang Kota Tuban. Penelitian menggunakan metode empiris untuk mendapatkan informasi dari pengamatan yang terjadi di lapangan dan hasil pengamatan tersebut disajikan berupa data. Hasil penelitian diketahui kinerja trayek A load factor rata-rata $81,39 \%$, frekuensi rata-rata $20,97 \mathrm{kend} / \mathrm{jam}$, headway rata-rata 2,88 menit, waktu tempuh rata-rata 3,50 menit/km, kecepatan tempuh rata-rata 21,52 km/jam, dan produktivitas 7,62 trip/hari-kend, dengan 74,45 pnp/hari-kend. Kinerja trayek B load factor rata-rata 78,19\%, frekuensi rata-rata 7,15 kend/jam, headway rata-rata 8,93 menit, waktu tempuh rata-rata 2,39 menit/km, kecepatan tempuh rata-rata 21,78 km/jam, dan produktivitas 7,74 trip/hari-kend, dengan 72,6 pnp/hari-kend..
\end{abstract}

Kata kunci: Angkutan Umum Penumpang; Kinerja; Produktivitas

Abstract. Passenger public transportation in Tuban is one of the means of transport used by the community to meet the transport needs. Total fleet of public transport passengers registered and active operating as many as 40 vehicles, consisting of 30 units of passenger public transportation route $A$ and 10 units of passenger public transportation route B, with a capacity of 12 passengers/vehicle. Passenger public transportation operates from 06.00 - 17.00 with the number of trips ranging from 7-8 trips/day every vehicle and can carry 9-10 passengers/trip every vehicle. The waiting time of passenger route A average of 3 minutes, and route $B$ average of 9 minutes. The purpose of research is to determine the performance and productivity of the passenger public transportation of Tuban. The research using empirical methods to obtain information from observations in the field and these observations are presented in the form of data.The research results it is known that the performance and productivity of public transportation on route A and B. Route A has an average load factor of 81,39\%, an average frequency of 20,97 vehicles/hour, an average headway of 2.88 minutes, an average travel time of 3,50 minutes/ $\mathrm{km}$, an average travel speed of $21,52 \mathrm{~km} / \mathrm{hour}$, and a productivity 7,62 trips/day-vehicle, with 74,45 passengers/day-vehicle. Route B has an average load factor of 78,19\%, an average frequency of 7,15 vehicles/hour, an average headway of 8,93 minutes, an average travel time of 2,39 minutes $/ \mathrm{km}$, an average travel speed of $21,78 \mathrm{~km} / \mathrm{hour}$, and a productivity 7,74 trips/day-vehicle, with 72,6 passengers/dayvehicle..

Keywords: Passenger Public Transportation; Performance; Productivity

\section{PENDAHULUAN}

Kota Tuban adalah salah satu kota yang terletak di Provinsi Jawa Timur. Dan merupakan kota yang memiliki potensi pariwisata dan perekonomian. Peningkatan perekonomian tersebut berdampak pada meningkatnya aktivitas serta arus pergerakan, baik arus pergerakan orang maupun barang, maka dituntut tersedianya angkutan perkotaan yang melayani penumpang dari Terminal Tuban menuju Terminal Tuban (rute melingkar), yang mana rute angkutan trayek A melewati jalan arteri, yang merupakan jalan dimana banyak kendaraan besar yang melintasi, sedangkan trayek B melewati jalan lokal, merupakan jalan yang banyak terdapat pertokoan dan pemukiman rumah warga. Maka untuk itulah akan diteliti bagaimana kinerja pelayanan angkutan kota Tuban, karena dilihat kurang optimalnya pelayanan angkutan kota tersebut dan menumpuknya angkutan perkotaan pada jam-jam sibuk disuatu tempat. Dalam penelitian ini, indikator yang akan digunakan antara lain load factor atau faktor muat, waktu antara, waktu perjalanan, frekuensi, jumlah kendaraan, waktu tunggu penumpang dan kecepatan rata-rata (Marsudi, 2006), (Ana dan Mashuri, 2012), (Fakhruriza et al, 2017).

Tujuan dari penelitian ini untuk mengetahui kinerja dan produktivitas angkutan umum penumpang Kota Tuban saat ini (2020). Adapun manfaat dari penelitian ini sebagai masukan dan bahan pertimbangan bagi instansi yang terkait untuk memperbaiki dan meningkatkan pelayanan angkutan umum penumpang di Kota Tuban. 


\section{Angkutan Umum Penumpang}

Undang-Undang Republik Indonesia No. 22 Pasal

138 Tahun 2009 menyatakan bahwa angkutan umum diselenggarakan oleh pemerintah untuk memenuhi kebutuhan pergerakan masyarakat dan tetap berpegang teguh pada kelancaran arus lalu lintas secara keseluruhan.

Peraturan Pemerintah Republik Indonesia No. 41 Tahun 1993 menyatakan bahwa angkutan perkotaan adalah angkutan dari suatu tempat ke tempat lain dalam wilayah kota dengan mempergunakan mobil angkutan umum penumpang yang terikat dalam trayek tetap dan teratur yang mempunyai sifat perjalanan ulang-alik. Angkutan umum penumpang adalah salah satu media transportasi yang digunakan masyarakat secara bersamasama dengan menerapkan sistem sewa atau bayar (Abadi dan Ruskandi, 2016). Angkutan umum penumpang terdiri dari angkutan kota, bus, minibus, kereta api, angkutan air dan angkutan udara. (Warpani, 1990)

Standar pelayanan merupakan parameter yang digunakan dalam menilai kualitas pelayanan angkutan umum baik itu secara keseluruhan maupun pada trayek tertentu yang meliputi : keselamatan, keandalan, fleksibilitas, kenyamanan, kecepatan, dan dampak. (Nasution, 2004)

\section{Kinerja Angkutan Umum Penumpang}

Load factor adalah perbandingan antara jumlah penumpang yang diangkut dalam kendaraan terhadap jumlah kapasitas kendaraan selama satu lintasan. Dirumuskan sebagai berikut :

$\mathrm{LF}=\mathrm{JP} / \mathrm{C} \times 100 \%$

Dimana :

LF $\quad=$ Load Factor $(\%)$

$\mathrm{JP}=$ Banyaknya penumpang yang diangkut sepanjang satu lintasan sekali jalan (Jumlah Penumpang) $\mathrm{C}$ = Daya kapasitan angkutan yang tersedia atau banyaknya tempat duduk

(Yohanes et al, 2015)

Menurut Morlok (1978) frekuensi adalah jumlah kendaraan yang lewat per satuan waktu. Dirumuskan sebagai berikut:

$\mathrm{F}=\mathrm{t} / \mathrm{H}$

Dimana :

$\mathrm{F} \quad=$ Frekuensi (kend/jam)

$\mathrm{t} \quad=$ Waktu (menit)

$\mathrm{H} \quad=$ Headway (menit)

Menurut Nasution (2004) headway adalah selisih waktu keberangkatan antara dua pelayanan angkutan umum pada satu titik tertentu atau selisih waktu kedatangan anatara kendaraan sebelumnya dengan kendaraan berikutnya. Dirumuskan sebagai berikut :

$\mathrm{H}=\mathrm{t} / \mathrm{F}$

Dimana :

$\mathrm{H} \quad=$ Headway (menit)

$$
\begin{array}{ll}
\mathrm{t} & =\text { Waktu (menit) } \\
\mathrm{F} & =\text { Frekuensi (kend/jam }
\end{array}
$$

Menurut Abadi Khoirul (2012) waktu yang diperlukan oleh angkutan umum penumpang untuk menempuh panjang trayek, dari titik awal sampai titik akhir dalam satuan menit/ kilometer. Dirumuskan sebagai berikut :

Waktu tempuh $=\mathrm{t} / \mathrm{S}$

Dimana :

$$
\begin{array}{ll}
\mathrm{S} & =\mathrm{Jarak}(\mathrm{km}) \\
\mathrm{t} & =\text { Waktu (menit) }
\end{array}
$$

Menurut Revy Safitri (2016) kecepatan rata - rata dari semua kendaraan yang melintas suatu titik di jalan selama periode waktu tertentu. Dirumuskan sebagai berikut :

$\mathrm{V}=\mathrm{S} / \mathrm{t}$.

Dimana :

$\mathrm{V}=$ Kecepatan tempuh $(\mathrm{km} / \mathrm{jam})$

$\mathrm{S} \quad=\operatorname{Jarak}(\mathrm{km})$

$\mathrm{t} \quad=$ Waktu (menit)

Menurut Marsudi (2006) jumlah kendaraan didefinisikan sebagai perbandingan antara jumlah kendaaraan yang tersedia dengan jumlah kendaraan yang beroperasi pada suatu trayek yang dinyatakan dalam persen (\%). Dirumuskan sebagai berikut :

Kendaraan beroperasi $=\mathrm{X} / \mathrm{Y} \times 100 \%$....(6)

Dimana :

$$
\begin{array}{ll}
\mathrm{X} & \text { = Jumlah kendaraan yang beroperasi } \\
\mathrm{Y} & \text { = Jumlah kendaraan yang tersedia }
\end{array}
$$

\section{Produktivitas AUP}

Menurut Anang Bakhtiar (2018) produktivitas dapat di rumuskan menggunakan formulasi sebagai berikut:

Jumlah Trip $=($ Rata-rata trip/hari $) /($ Kendaran yang beroperasi)...(7)

$\mathrm{P}$

roduktivitas $=$ Jumlah penumpang rata-rata (pnp/tripkend) $\mathrm{x}$ Jumlah trip rata-rata (trip/hari-kend)

\section{METODE}

Metode penelitian yang digunakan dalam penelitian ini adalah metode survei, yang meliputi pengumpulan data primer dan data sekunder. Pengumpulan data primer dilakukan dengan melakukan wawancara langsung dengan pengguna jasa angkutan umum penumpang dan pencatatan data jumlah penumpang di lokasi penelitian.

Lokasi yang ditinjau sebagai tempat penelitian disajikan pada gambar 1 . 
Andi Syaiful Amal, Shaufi Kholif Arfintana dan Khoirul Abadi, Analisa Kinerja Angkutan Umum Penumpang Perkotaan

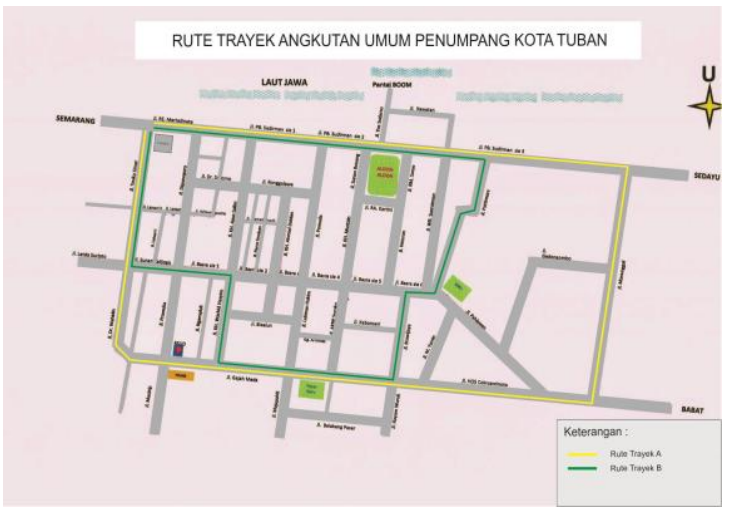

Gambar 1. Layout Lokasi Penelitian

Sumber : Dinas Perhubungan Kabupaten Tuban

\section{HASIL DAN PEMBAHASAN \\ Data Angkutan Umum Penumpang \\ Data Penumpang}

Data penumpang diperoleh berdasarkan survei di lokasi, (pukul 06.00 WIB sampai 17.00 WIB). Data penumpang AUP Trayek A dan B disajikan pada tabel 1.

Tabel 1. Data Penumpang AUP Trayek A dan B (pnp/trip-kend)

\begin{tabular}{|c|c|c|c|c|c|c|c|c|c|c|}
\hline \multirow{3}{*}{ Jam Berangkat } & \multicolumn{10}{|c|}{ Hari } \\
\hline & \multicolumn{2}{|c|}{ Sabtu } & \multicolumn{2}{|c|}{ Senin } & \multicolumn{2}{|c|}{ Selasa } & \multicolumn{2}{|c|}{ Rabu } & \multicolumn{2}{|c|}{ Kamis } \\
\hline & A & B & A & B & A & B & A & B & A & B \\
\hline 06:00 & 10 & 11 & 12 & 13 & 13 & 10 & 11 & 12 & 10 & 12 \\
\hline $07: 00$ & 12 & 12 & 9 & 11 & 10 & 10 & 9 & 9 & 10 & 11 \\
\hline 08:00 & 9 & 10 & 8 & 9 & 9 & 8 & 8 & 9 & 10 & 9 \\
\hline 09:00 & 7 & 9 & 9 & 8 & 8 & 9 & 9 & 7 & 9 & 9 \\
\hline $10: 00$ & 9 & 6 & 9 & 8 & 8 & 9 & 7 & 8 & 8 & 9 \\
\hline $11: 00$ & 8 & 8 & 8 & 8 & 9 & 6 & 9 & 9 & 9 & 8 \\
\hline $12: 00$ & 10 & 8 & 12 & 9 & 10 & 7 & 11 & 8 & 9 & 9 \\
\hline $13: 00$ & 11 & 12 & 11 & 12 & 12 & 11 & 11 & 12 & 12 & 12 \\
\hline $14: 00$ & 10 & 11 & 12 & 11 & 12 & 11 & 13 & 12 & 11 & 12 \\
\hline $15: 00$ & 12 & 9 & 11 & 10 & 10 & 9 & 10 & 7 & 9 & 9 \\
\hline $16: 00$ & 10 & 9 & 10 & 9 & 11 & 8 & 11 & 8 & 10 & 10 \\
\hline $17: 00$ & 7 & 9 & 7 & 7 & 8 & 8 & 9 & 9 & 8 & 8 \\
\hline
\end{tabular}

Sumber : Hasil Survei

Tabel 2. Durasi Tempuh AUP Trayek A dan B (menit)

\begin{tabular}{|c|c|c|c|c|c|c|c|c|c|c|}
\hline \multirow{3}{*}{ Jam Berangkat } & \multicolumn{10}{|c|}{ Hari } \\
\hline & \multicolumn{2}{|c|}{ Sabtu } & \multicolumn{2}{|c|}{ Senin } & \multicolumn{2}{|c|}{ Selasa } & \multicolumn{2}{|c|}{ Rabu } & \multicolumn{2}{|c|}{ Kamis } \\
\hline & $\mathrm{A}$ & $\mathrm{B}$ & $\mathrm{A}$ & $\mathrm{B}$ & $\mathrm{A}$ & $\mathrm{B}$ & $\mathrm{A}$ & $\mathrm{B}$ & $\mathrm{A}$ & $\mathrm{B}$ \\
\hline 06:00 & 43 & 34 & 45 & 36 & 43 & 36 & 45 & 37 & 38 & 37 \\
\hline 07:00 & 41 & 34 & 43 & 37 & 39 & 33 & 41 & 35 & 42 & 37 \\
\hline 08:00 & 45 & 37 & 45 & 35 & 41 & 35 & 44 & 38 & 42 & 38 \\
\hline 09:00 & 41 & 38 & 40 & 38 & 43 & 36 & 41 & 34 & 45 & 37 \\
\hline $10: 00$ & 41 & 34 & 44 & 37 & 46 & 38 & 42 & 36 & 37 & 36 \\
\hline $11: 00$ & 44 & 36 & 41 & 35 & 40 & 37 & 41 & 39 & 41 & 36 \\
\hline $12: 00$ & 41 & 36 & 41 & 33 & 41 & 36 & 43 & 36 & 41 & 33 \\
\hline $13: 00$ & 44 & 34 & 44 & 35 & 44 & 38 & 41 & 36 & 40 & 34 \\
\hline $14: 00$ & 45 & 37 & 39 & 35 & 41 & 36 & 41 & 38 & 38 & 37 \\
\hline $15: 00$ & 43 & 35 & 41 & 38 & 42 & 33 & 38 & 37 & 43 & 37 \\
\hline $16: 00$ & 44 & 35 & 43 & 33 & 43 & 36 & 46 & 36 & 41 & 38 \\
\hline $17: 00$ & 42 & 34 & 43 & 34 & 44 & 33 & 39 & 37 & 39 & 36 \\
\hline
\end{tabular}

Sumber : Hasil Survei

\section{Kinerja Angkutan Umum Penumpang Rekapitulasi Jumlah Penumpang}

Rekapitulasi jumlah penumpang angkutan umum penumpang diperoleh berdasarkan data penumpang AUP (tabel 1).

Rekapitulasi jumlah penumpang AUP disajikan pada tabel 3 dan 4.
Tabel 3. Rekapitulasi Jumlah Penumpang AUP Trayek A ( pnp/trip-kend

\begin{tabular}{lccccc}
\hline & \multicolumn{5}{c}{ Hari } \\
\cline { 2 - 6 } \multicolumn{1}{c}{ Jam Brk. } & Sabtu & Senin & Selasa & Rabu & Kamis \\
\hline Maks. & 12 & 12 & 13 & 13 & 12 \\
Min. & 7 & 7 & 8 & 7 & 8 \\
Rata-rata & 10 & 10 & 11 & 10 & 10 \\
\hline Maks. & & 13 & & \\
Min. & & 7 & & \\
Rata-rata & & 10 &
\end{tabular}


Tabel 4. Rekapitulasi Jumlah Penumpang AUP Trayek B (pnp/trip-kend )

\begin{tabular}{lccccc}
\hline & \multicolumn{5}{c}{ Hari } \\
\cline { 2 - 6 } Jam Brk. & Sabtu & Senin & Selasa & Rabu & Kamis \\
\hline Maks. & 12 & 13 & 11 & 12 & 12 \\
Min. & 6 & 7 & 6 & 7 & 8 \\
Rata-rata & 9 & 10 & 9 & 9 & 10 \\
\hline Maks. & & & 13 & & \\
Min. & & & 6 & & \\
Rata-rata & & & 9 & & \\
\hline
\end{tabular}

Sumber : Hasil perhitungan

Dari rekapitulasi jumlah penumpang AUP trayek A, jumlah penumpang maksimum 13 pnp/trip-kend. Dan minimum 7 pnp/trip-kend. Serta rata-rata 10 pnp/tripkend. Sedangkan trayek $\mathrm{B}$, jumlah penumpang maksimum 13 pnp/trip-kend. Dan minimum 6 pnp/tripkend. Serta rata-rata 9 pnp/trip-kend.

\section{Faktor Muat ( Load Factor )}

Faktor muat angkutan umum penumpang dihitung dengan persamaan 1 .

Faktor muat (load factor) AUP disajikan pada tabel 5 dan 6.

Tabel 5. Faktor Muat AUP Trayek A ( \%)

\begin{tabular}{lccccc}
\hline & \multicolumn{5}{c}{ Hari } \\
\cline { 2 - 6 } Jam Brk. & Sabtu & Senin & Selasa & Rabu & Kamis \\
\hline Maks. & 100,00 & 100,00 & 108,33 & 108,33 & 100,00 \\
Min. & 58,33 & 58,33 & 66,67 & 58,33 & 66,67 \\
Rata-rata & 79,86 & 81,94 & 83,33 & 81,94 & 79,86 \\
\hline Maks. & & & 108,33 & & \\
Min. & & 58,33 & & \\
Rata-rata & & 81,39 & &
\end{tabular}

Sumber : Hasil perhitungan

Tabel 6. Faktor Muat AUP Trayek B ( \% )

\begin{tabular}{lccccc}
\hline & \multicolumn{5}{c}{ Hari } \\
\cline { 2 - 6 } Jam Brk. & Sabtu & Senin & Selasa & Rabu & Kamis \\
\hline Maks. & 100,00 & 108,33 & 91,67 & 100,00 & 100,00 \\
Min. & 50,00 & 58,33 & 50,00 & 58,33 & 66,67 \\
Rata-rata & 79,17 & 79,86 & 73,61 & 76,39 & 81,94 \\
\hline Maks. & & & 108,33 & & \\
Min. & & 50,00 & & \\
Rata-rata & & 78,19 & \\
\hline
\end{tabular}

Sumber : Hasil perhitungan

Angkutan umum penumpang trayek A dengan load factor maksimum $108,33 \%$, minimum $58,33 \%$, dan rata-rata $81,39 \%$. Sedangkan trayek B dengan load factor maksimum $108,33 \%$, minimum $50,00 \%$, dan rata-rata $78,19 \%$. Load factor rata-rata penumpang AUP trayek A dan B masih diatas standar yang telah ditetapkan sebesar $70 \%$.

Dari rekapitulasi penumpang maksimum di dalam angkutan umum penumpang (POV) trayek A dan B jumlah penumpang maksimum sebanyak 7 penumpang. Berdasarkan jumlah penumpang maksimum di dalam angkutan umum penumpang (POV) sebesar 7 penumpang, dimana jumlah penumpang maksimum di dalam kendaraan lebih kecil dari kapasitas yang tersedia yaitu 12 penumpang, artinya dengan kondisi seperti ini penumpang masih nyaman berada di dalam kendaraan angkutan umum.

\section{Frekuensi dan Headway}

Frekuensi dan headway angkutan umum penumpang trayek A dan B dihitung dengan persamaan 2 dan 3 Frekuensi AUP disajikan pada tabel 7 dan 8, dan headway AUP disajikan pada tabel 9 dan 10.

Tabel 7. Frekuensi AUP Trayek A ( kend/jam )

\begin{tabular}{lccccc}
\hline & \multicolumn{5}{c}{ Hari } \\
\cline { 2 - 6 } \multicolumn{1}{c}{ Sabtu } & Senin & Selasa & Rabu & Kamis \\
\hline Maks. & 24 & 23 & 24 & 24 & 23 \\
Min. & 18 & 17 & 18 & 17 & 19 \\
Rata-rata & 22 & 20 & 22 & 22 & 22 \\
\hline Maks. & & & 24 & & \\
Min. & & & 17 & & \\
Rata-rata & & & 21 & & \\
\hline
\end{tabular}

Sumber : Hasil perhitungan

Tabel 8. Frekuensi AUP Trayek B ( kend/jam )

\begin{tabular}{lccccc}
\hline & \multicolumn{5}{c}{ Hari } \\
\cline { 2 - 6 } & Sabtu & Senin & Selasa & Rabu & Kamis \\
\hline Maks. & 11 & 10 & 9 & 10 & 9 \\
Min. & 5 & 5 & 4 & 5 & 4 \\
Rata-rata & 8 & 8 & 7 & 7 & 6 \\
\hline Maks. & & & 11 & & \\
Min. & & & 4 & & \\
Rata-rata & & & 7 & & \\
\hline
\end{tabular}

Sumber : Hasil perhitungan

Angkutan umum penumpang trayek A, frekuensi maksimum $24 \mathrm{kend} / \mathrm{jam}$, minimum $17 \mathrm{kend} / \mathrm{jam}$, dan rata-rata $20,97 \mathrm{kend} / \mathrm{jam}$. Sedangkan trayek $\mathrm{B}$, frekuensi maksimum 11 kend/jam, minimum 4 kend/jam, dan ratarata $7,15 \mathrm{kend} / \mathrm{jam}$.

Tabel 9. Headway AUP Trayek A ( menit )

\begin{tabular}{lrrccc}
\hline & \multicolumn{5}{c}{ Hari } \\
\cline { 2 - 6 } & Sabtu & Senin & Selasa & Rabu & Kamis \\
\hline Maks. & 3,33 & 3,53 & 3,33 & 3,53 & 3,16 \\
Min. & 2,50 & 2,61 & 2,50 & 2,50 & 2,61 \\
Rata-rata & 2,88 & 2,97 & 3,00 & 3,00 & 2,89 \\
\hline Maks. & & & 3,53 & & \\
Min. & & 2,50 & & \\
Rata-rata & & 2,88 & & \\
\hline
\end{tabular}

Sumber : Hasil perhitungan

Tabel 10. Headway AUP Trayek B ( menit )

\begin{tabular}{lccccc}
\hline & \multicolumn{5}{c}{ Hari } \\
\cline { 2 - 6 } \multicolumn{1}{c}{ Maktu } & Senin & Selasa & Rabu & Kamis \\
\hline Min. & 12,00 & 12,00 & 15,00 & 12,00 & 15,00 \\
Rata-rata & 5,45 & 6,00 & 6,67 & 6,00 & 6,67 \\
\hline Maks. & 8,44 & 8,36 & 9,51 & 8,90 & 10,01 \\
Min. & & & 15,00 & & \\
Rata-rata & & & 5,45 & & \\
\hline
\end{tabular}

Sumber : Hasil perhitungan

Angkutan umum penumpang trayek A, headway maksimum 3,53 menit, minimum 2,50 menit, dan ratarata 2,88 menit. Sedangkan trayek $B$, headway 
maksimum 15,00 menit, minimum 5,45 menit, rata-rata 8,93 menit.

\section{Waktu Tempuh (Journey Time)}

Waktu tempuh (Journey Time) angkutan umum penumpang dihitung dengan persamaan 4 berdasarkan durasi tempuh (tabel 3). Waktu tempuh AUP disajikan pada tabel 11 dan 12 .

Tabel 11. Waktu Tempuh AUP Trayek A ( menit/km )

\begin{tabular}{lrrrrc}
\hline & \multicolumn{5}{c}{ Hari } \\
\cline { 2 - 6 } Jam Brk. & Sabtu & Senin & Selasa & Rabu & Kamis \\
\hline Maks. & 3,00 & 3,00 & 3,07 & 3,07 & 3,00 \\
Min. & 2,73 & 2,60 & 2,60 & 2,53 & 2,47 \\
Rata-rata & 2,86 & 2,83 & 2,82 & 2,79 & 2,71 \\
\hline Maks. & & & 3,07 & & \\
Min. & & 2,47 & & \\
Rata-rata & & 2,80 & & \\
\hline
\end{tabular}

Sumber : Hasil perhitungan

Tabel 12. Waktu Tempuh AUP Trayek B ( menit/km )

\begin{tabular}{lrrccc}
\hline & \multicolumn{5}{c}{ Hari } \\
\cline { 2 - 6 } Jam Brk. & Sabtu & Senin & Selasa & Rabu & Kamis \\
\hline Maks. & 2,53 & 2,53 & 2,53 & 2,60 & 2,53 \\
Min. & 2,27 & 2,20 & 2,20 & 2,27 & 2,20 \\
Rata-rata & 2,36 & 2,37 & 2,37 & 2,44 & 2,42 \\
\hline Maks. & & & 2,60 & & \\
Min. & & 2,20 & & \\
Rata-rata & & 2,39 & & \\
\hline
\end{tabular}

Sumber : Hasil perhitungan

Angkutan umum penumpang trayek A, waktu tempuh maksimum 3,07 menit/km, minimum 2,47 menit $/ \mathrm{km}$, rata-rata $2,80 \mathrm{menit} / \mathrm{km}$. Sedangkan trayek B, waktu tempuh maksimum 2,60 menit $/ \mathrm{km}$, minimum 2,20 menit $/ \mathrm{km}$, dan rata-rata 2,39 menit $/ \mathrm{km}$.

\section{Kecepatan Tempuh (Journey Speed)}

Kecepatan tempuh angkutan umum penumpang dihitung dengan menggunakan persamaan 5 .

Tabel 13. Kecepatan Tempuh AUP Trayek A ( km/jam )

\begin{tabular}{lccccc}
\hline & \multicolumn{5}{c}{ Hari } \\
\cline { 2 - 6 } Jam Brk. & Sabtu & Senin & Selasa & Rabu & Kamis \\
\hline Maks. & 22,06 & 23,08 & 23,08 & 23,81 & 24,19 \\
Min. & 20,00 & 20,00 & 19,48 & 19,48 & 20,00 \\
Rata-rata & 21,08 & 21,27 & 21,35 & 21,62 & 22,26 \\
\hline Maks. & & & 24,19 & & \\
Min. & & 19,48 & & \\
Rata-rata & & 21,52 & & \\
\hline
\end{tabular}

Sumber : Hasil perhitungan

Tabel 14. Kecepatan Tempuh AUP Trayek B ( km/jam )

\begin{tabular}{lccccc}
\hline & \multicolumn{5}{c}{ Hari } \\
\cline { 2 - 6 } Jam Brk. & Sabtu & Senin & Selasa & Rabu & Kamis \\
\hline Maks. & 22,94 & 23,64 & 23,64 & 22,94 & 23,64 \\
Min. & 20,53 & 20,53 & 20,53 & 20,00 & 20,53 \\
Rata-rata & 22,10 & 22,02 & 21,97 & 21,34 & 21,49 \\
\hline Maks. & & & 23,64 & & \\
Min. & & 20,00 & & \\
Rata-rata & & 21,78 & & \\
\hline
\end{tabular}

Sumber : Hasil perhitungan

\section{Produktivitas AUP}

\section{Trip Angkutan Umum Penumpang}

Jumlah trip kendaraan diperoleh berdasarkan data jumlah kendaraan AUP yang beroperasi perhari . Trip AUP disajikan pada tabel 15 dan 16.

Tabel 15. Trip AUP Trayek A (trip/hari-kend)

\begin{tabular}{lccccc}
\hline \multirow{1}{*}{ Jam Brk. } & \multicolumn{5}{c}{ Hari } \\
\cline { 2 - 6 } & Sabtu & Senin & Selasa & Rabu & Kamis \\
\hline Jumlah & 234 & 226 & 225 & 224 & 234 \\
Rata-rata trip/hari & & & 228,60 & & \\
Rata-rata trip/hari- & & & 7,62 & & \\
kend. & & & & & \\
\hline
\end{tabular}

Sumber : Hasil perhitungan

Tabel 16. Trip AUP Trayek B (trip/hari-kend)

\begin{tabular}{lccccc}
\hline & \multicolumn{5}{c}{ Hari } \\
\cline { 2 - 6 } Jam Brk. & Sabtu & Senin & Selasa & Rabu & Kamis \\
\hline Jumlah & 83 & 83 & 74 & 78 & 69 \\
Rata-rata trip/hari & & & 77,40 & & \\
Rata-rata trip/hari- & & & 7,74 & & \\
kend. & & & & & \\
\hline
\end{tabular}

Sumber : Hasil perhitungan

\section{Pembahasan}

\section{Angkutan Umum Penumpang Trayek A}

Angkutan umum penumpang yang terdaftar dan aktif beroperasi berjumlah 30 kendaraan. Waktu pelayanan angkutan umum penumpang yaitu 11 jam, beroperasi mulai dari pukul 06.00-17.00.

Load factor angkutan umum penumpang dengan load factor maksimum sebesar 108,33\% (13 penumpang) dan load factor rata-rata $81,39 \%$ (9,77 penumpang). Dengan ini diartikan bahwa tingkat keterisian angkutan umum penumpang lebih dari okupansi $70 \%$. Berdasarkan penumpang maksimum di dalam kendaraan (POV) sebanyak 7 penumpang, dimana jumlah penumpang lebih kecil dari kapasitas angkutan umum penumpang yang tersedia yaitu 12 orang. Artinya angkutan umum penumpang masih dalam kondisi nyaman tidak berdesakan, karena jumlah penumpang maksimum di dalam angkutan umum penumpang (POV) tidak melebihi dari kapasitas yang tersedia.

Frekuensi angkutan umum penumpang rata-rata sebesar 20,97 kend/jam dan headway rata-rata sebesar 2,88 menit. Dengan demikian calon penumpang membutuhkan waktu tunggu 2,88 menit, untuk menunggu angkutan umum penumpang selanjutnya. Berdasarkan penumpang maksimum di dalam kendaraan (POV) sebanyak 7 penumpang, dimana jumlah penumpang lebih kecil dari kapasitas yang tersedia yaitu 12 orang. Artinya waktu tunggu rata-rata 2,88 menit, calon penumpang bisa mendapatkan angkutan umum penumpang.

Kecepatan tempuh angkutan umum penumpang rata-rata sebesar $21,52 \mathrm{~km} / \mathrm{jam}$ dengan waktu tempuh rata-rata sebesar $2,80 \mathrm{menit} / \mathrm{km}$. Kecepatan tempuh dan waktu tempuh angkutan umum penumpang juga dipengaruhi oleh beberapa faktor eksternal, karena rute 
yang dilewati diantaranya jalan arteri, yang merupakan jalan dimana banyak kendaraan besar yang melintasi.

Produktivitas angkutan umum penumpang trayek A rata-rata 7,62 trip/hari-kend dengan penumpang ratarata $74,45 \mathrm{pnp} /$ hari-kend. Sedangkan trayek B rata-rata 7,74 trip/hari-kend dengan penumpang rata-rata 72,6 pnp/hari-kend.

\section{Angkutan Umum Penumpang Trayek B}

Angkutan umum penumpang yang terdaftar dan aktif beroperasi berjumlah 10 kendaraan. Waktu pelayanan angkutan umum penumpang yaitu 11 jam, beroperasi mulai dari pukul 06.00-17.00.

Load factor angkutan umum penumpang dengan load factor maksimum sebesar $108,33 \%$ (13 penumpang) dan load factor rata-rata $78,19 \%$ (9,38 penumpang). Dengan ini diartikan bahwa tingkat keterisian angkutan umum penumpang lebih dari okupansi $70 \%$. Berdasarkan penumpang maksimum di dalam kendaraan (POV) sebanyak 7 penumpang, dimana jumlah penumpang lebih kecil dari kapasitas angkutan umum penumpang yang tersedia yaitu 12 orang. Artinya angkutan umum penumpang masih dalam kondisi nyaman tidak berdesakan, karena jumlah penumpang maksimum di dalam angkutan umum penumpang (POV) tidak melebihi dari kapasitas yang tersedia.

Frekuensi angkutan umum penumpang rata-rata sebesar 7,15 kend/jam dan headway rata-rata sebesar 8,93 menit. Dengan demikian calon penumpang membutuhkan waktu tunggu 8,93 menit, untuk menunggu angkutan umum penumpang selanjutnya. Berdasarkan penumpang maksimum di dalam kendaraan (POV) sebanyak 7 penumpang, dimana jumlah penumpang lebih kecil dari kapasitas yang tersedia yaitu 12 orang. Artinya waktu tunggu rata-rata 8,93 menit, calon penumpang bisa mendapatkan angkutan umum penumpang. Dari waktu tunggu rata-rata 8,93 menit, maka angkutan umum penumpang memerlukan perbaikan headway dengan cara menambah kendaraan, tetapi dengan adanya penambahan kendaraan load factor akan menurun.

Kecepatan tempuh angkutan umum penumpang rata-rata sebesar 21,78 dengan waktu tempuh rata-rata sebesar 2,39 menit $/ \mathrm{km}$. Kecepatan tempuh dan waktu tempuh angkutan umum penumpang juga dipengaruhi oleh beberapa faktor eksternal, karena rute yang dilewati diantaranya jalan lokal, merupakan jalan yang banyak terdapat pertokoan dan pemukiman rumah warga.

Produktivitas angkutan umum penumpang berdasarkan trip rata-rata sebesar 7,74 trip/hari-kend dengan penumpang rata-rata sebesar 9,38 pnp/hari-kend, maka diekivalenkan produktivitas sebesar 72,6 pnp/harikend.

\section{Tinjauan Rute Angkutan Umum Penumpang}

Terdapat kesamaan rute disebagian segmen jalan (Jl. P. Jendral Sudirman, Jl. Gajah Mada dan Jl. Teuku
Umar) dimana jalan tersebut dilewati angkutan umum penumpang trayek A dan B. Adanya tata guna lahan dengan kepadatan penduduk yang tinggi disekitar rute yang dilewati angkutan umum penumpang. Pada rute yang dilewati angkutan umum penumpang trayek A, di kawasan jalan P. Jendral Sudirman terdapat pemukiman rumah warga dan beberapa pertokoan, di kawasan jalan Manunggal terdapat beberapa sekolah dan rumah makan, dan di kawasan jalan HOS. Cokroaminoto terdapat perindustrian dan perkantoran. Sedangkan pada rute yang dilewati angkutan umum penumpang trayek B, di kawasan jalan Patimura sampai dengan kawasan jalan Brawijaya terdapat beberapa pertokoan, pemukiman rumah warga, dan beberapa sekolah, dan di kawasan jalan Wahid Hasyim sampai dengan kawasan jalan Sunan Kalijogo terdapat beberapa pertokoan dan rumah makan. Banyaknya penumpang yang menggunakan jasa angkutan umum juga dipengaruhi oleh tata guna lahan dengan kepadatan penduduk yang tinggi. Kesamaan rute pada sebagian segmen jalan (Jl. P. Jendral Sudirman, Jl. Gajah Mada dan Jl. Teuku Umar) mengakibatkan dampak bagi angkutan umum penumpang trayek A dan B. Sehingga trayek A dengan jumlah armada 30 kendaraan lebih banyak mengangkut penumpang dibandingkan dengan trayek $B$ yang mana jumlah armada hanya 10 kendaraan.

\section{SIMPULAN}

Kinerja angkutan umum penumpang trayek A load factor rata-rata $81,39 \%$, frekuensi rata-rata 20,97 $\mathrm{kend} / \mathrm{jam}$, headway rata-rata 2,88 menit, waktu tempuh rata-rata 3,50 menit/km, dan kecepatan tempuh rata-rata $21,52 \mathrm{~km} / \mathrm{jam}$. Sedangkan trayek B load factor rata-rata $78,19 \%$, frekuensi rata-rata $7,15 \mathrm{kend} / \mathrm{jam}$, headway rata-rata 8,93 menit, waktu tempuh rata-rata 2,39 menit $/ \mathrm{km}$, dan kecepatan tempuh rata-rata $21,78 \mathrm{~km} / \mathrm{jam}$. Produktivitas angkutan umum penumpang berdasarkan trip rata-rata sebesar 7,62 trip/hari-kend dengan penumpang rata-rata sebesar 9,77 pnp/hari-kend, maka diekivalenkan produktivitas sebesar 74,45 pnp/harikend.

\section{DAFTAR PUSTAKA}

Abadi, Khoirul, 2012, Kajian Biaya Operasional Kendaraan Angkutan Umum Kota Malang, Jurnal Media Teknik Sipil, ISSN 1693-3095, Vol.10 No.1

Abadi, Khoirul, dan Ruskandi, 2016, Evaluasi Kebutuhan Angkutan Umum Penumpang Kota Malang, Jurnal Media Teknik Sipil, ISSN 16933095, Vol.14 No.1

Ana, Febrianti, dan Mashuri, 2012, Studi Kebutuhan Angkutan Umum Penumpang Perkotaan di Kota Palu, Jurnal Rekayasa dan Manajemen Transportasi, Vol.II, No.1

Anang, Bakhtiar, 2018, Evaluasi Kinerja Angkutan Umum Kota Malang, Jurnal JU-Ke, Vol. 2, No. 2 
Andi Syaiful Amal, Shaufi Kholif Arfintana dan Khoirul Abadi, Analisa Kinerja Angkutan Umum Penumpang Perkotaan Ditinjau Dari Tingkat Pelayanan di Kota Tuban

Marsudi, M, 2006, "Analisa Kinerja Mobil Penumpang Umum (MPU) dan Sistem Jaringan Trayek di Kota Salatiga", Jurnal Pilar Vol. 15 No. 2 Hal. 107-116 (Doctoral dissertation, Magister Teknik Sipil).

M. Fakhruriza Pradana, Dwi Esti I, Linta A, 2017, Evaluasi Kinerja Pelayanan Dan Jumlah Armada Angkutan Umum di Kota Tangerang, Jurnal Fondasi, Vol. 6, No. 2

Morlok, Edward K. 1978. Pengantar Teknik dan Perencanaan Transportasi Terjemahan Oleh Ir. Johan Kelananputra Haimin. 1995. Erlangga. Jakarta: Erlangga.

Nasution, M. N. 2004, Manajemen Transportasi. Jakarta : Ghalia Indonesia.

Peraturan Pemerintah Republik Indonesia No. 41 Tahun 1993. Tentang Angkutan Jalan.

Revy, Safitri, 2016, Evaluasi Tarif Angkutan Umum Berdasarkan Ability To Pay dan Willingness To Pay di Kota Pangkalpinang, Jurnal Fropil, Vol. 4, No. 2

Undang-Undang Republik Indonesia Nomor 22 Tahun 2009. Tentang Lalu lintas dan Angkutan Jalan.

Warpani, Suwardjoko P. 1990. Merencanakan Sistem Pengangkutan. Penerbit ITB. Bandung.

Yohanes T. Safe, I Made Udiana, Rosmiyati A Bella, 2015, Evaluasi Kinerja Angkutan Umum Trayek Terminal Oebobo - Terminal Kupang PP dan Terminal Kupang - Terminal Noelbaki PP, Jurnal Teknik Sipil, Vol. IV, No. 1. 